\title{
1 The Middle Stone Age Archaeology of the Senegal River Valley
}

2 Eleanor M. L. Scerri ${ }^{1 *}$, James Blinkhorn ${ }^{2}$, Huw S. Groucutt ${ }^{1}$ and Khadija Niang ${ }^{3}$

3

4

5

6

7

8

9

10

11

12

${ }^{1}$ School of Archaeology, University of Oxford, 36 Beaumont Street, Oxford OX1 2HU, U.K.

${ }^{2} \mathrm{McDonald}$ Institute of Archaeological Research, University of Cambridge, Downing Street, Cambridge CB2 3ER, U.K.

${ }^{3}$ Faculté des Lettres et Sciences Humaines, Cheikh Anta Diop University, UCAD, BP 5005 Fann Dakar, Senegal

*Corresponding author, eleanor.scerri@rlaha.ox.ac.uk

\section{Abstract}

The importance of Africa in human origins is widely recognised, yet knowledge remains strongly biased towards certain regions of the continent at the expense of others. West Africa in particular is a vast area with extremely limited archaeological, environmental and fossil records. In this paper, we contribute towards redressing this imbalance though a summary of the state of knowledge of the West African Middle Stone Age (MSA), and the presentation of preliminary analyses of ten newly discovered MSA archaeological sites situated along the Senegal River. Archaeological, fossil and genetic data relevant to the West African MSA, a period currently thought to span from at least 150 thousand years ago $(\mathrm{ka})$ until the Terminal Pleistocene, are first discussed. Technological analyses of newly discovered MSA assemblages in Senegal are then presented and contextualised with the ecology and environmental evolution of West Africa. Our preliminary findings suggest an overall high level of technological diversity along the Senegal River, but identify common technological features between assemblages in northern Senegal. These include an emphasis on centripetal methods of Levallois reduction (both preferential and recurrent). The discovery of tools in northern Senegal with basal modifications consistent with tanging may also suggest some form of connection with North African assemblages and is commensurate with the role of Senegal as a transitional zone between sub-Saharan and Saharan Africa. Although preliminary, the emerging results demonstrate the potential of the region to contribute to debates on intra-African dispersals, including population persistence and turnovers.

Keywords: Middle Stone Age, Aterian, West Africa, intra African dispersals, human evolution

\section{Introduction}

Africa is generally regarded as the birthplace of our species, as well as a key area for hominin evolution. However, little is known about the continental variability of Pleistocene archaeological, fossil and climatic records beyond the relatively intensively researched areas of South and East Africa (including northeast Africa) and the Maghreb (Willoughby, 2007; Barham and Mitchell, 2008). This patchy state of knowledge is increasingly problematic given the growing requirement for a fuller 
understanding of the African Stone Age, involving spatially and temporally representative samples from across the continent. Fuelling the need to fill this research gap are fossil and genetic data indicating a complex transition to Homo sapiens, involving multiple sets of spatially subdivided African populations (Gunz et al., 2009; Crevecoeur et al., 2010; Scally and Durbin, 2012; Scerri et al., 2014).

In the light of such scientific insights, the current lack of Pleistocene hominin fossils, together with weak and/or patchy chronological control on a poorly understood archaeological record is problematic. The only known early human skeletal remains to come from West Africa are from the Iwo Eleru rockshelter in southwestern Nigeria. The skeleton was found in an undisturbed Later Stone Age (LSA) context

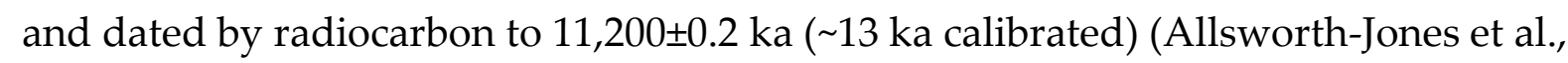
2010; Harvati et al., 2011) and between 11,700 $\pm 1.7 \mathrm{ka}$ and $\sim 16.3 \pm 0.5 \mathrm{ka}$ by Uranium series (Harvati et al., 2011). However, despite this terminal Pleistocene/early Holocene (Marine Isotope Stage [MIS] 1 or 2) date, the skull presents a mosaic of primitive and derived features (Brothwell and Shaw, 1971; Stringer, 1974). Harvati and colleagues (2011) found the skull to be outside the range of modern human variability, and similar to the $\sim 100 \mathrm{ka} H o m o$ sapiens specimens from the Middle Eastern sites of Skhul and Qafzeh. The young age was taken by these authors to suggest a complex transition to anatomical 'modernity'. The late survival of 'archaic' features is likely to represent a deep and persistent population substructure in Africa, a conclusion also reached by other fossil and archaeological studies (Gunz et al., 2009; Crevecoeur et al., 2010; Scerri et al., 2014).

Like the archaeological and palaeontological records of West Africa, genetic analyses have also emphasised the role of a deep and persistent African population structure in the Pleistocene. In this model, highly structured hominin lineages in multiple regions of Africa branched out and refused with the passage of time, consistent with the highly variable expression of 'anatomical modernity' as recently as the early Holocene discussed above. However, unlike the limited archaeological and palaeontological data, genetic research relevant to West African population history provides some concrete insights.

The depth of population substructure is demonstrated by the discovery that the most basal Y-chromosome lineage has a time to most recent common ancestor (TMRCA) of $\sim 338 \mathrm{ka}$ (Mendez et al., 2013). Like the evidence from the Iwo Eleru rockshelter supporting a late persistence of population substructure, this very early evidence is also linked to West Africa, specifically to West African Mbo populations (Mendez et al., 2013). Of note in this context, is the fact that after the Khoe-San of southern Africa, the Pygmy populations of central and the fringes of western Africa are the most genetically divergent contemporary human populations in the world 
1 (Veeramah and Hammer, 2014). Furthermore, West Africa is also linked with

2 possible archaic African hominin admixture (Garrigan et al., 2005; Scally and Durbin,

3 2012; Veeramah and Hammer, 2014). Specifically, Whole Genome Sequencing (WGS)

4 models suggest that that western and central Africa may have been critical regions of

5 admixture (Hammer et al., 2011; Veeramah and Hammer, 2014).

6 These recent insights on population-level processes in West Africa during the

7 Middle and Late Pleistocene suggest that the region may help resolve questions

8 regarding intra-African demography and dispersals. In particular, West Africa may

9 shed light on the complexity of population persistence and exchange over the

\section{The Stone Age of Senegal and West Africa}

\subsection{Geographic and environmental contexts}

Modern Senegal spans three biogeographic zones - Sahelian, savannah and forested - and palaeoclimate models indicate that these zones are unlikely to have shifted significantly during the Late Pleistocene (Fig. 1; Scerri et al., 2014). This is a very different picture from that of other areas such as North Africa and Arabia (see e.g. Jennings et al., in press). As a result, the MSA in Senegal can be investigated in very different, but closely neighbouring environments, at the transition between the Sahara and the Sahel. The Senegal River and its network of tributaries are also critical features of the region because they link the African interior to the coast and arid northern Africa, where they provide a major source of fresh water during the dry season.

Figure 1 hereabouts

The Senegal River drains parts of Guinea and Mali in its upper reaches, and forms the border between Senegal and Mauritania in its lower course, in total flowing for $\sim 1800 \mathrm{~km}$. The Falémé, delineating much of the border between Mali and Senegal, is the major tributary of the Senegal River. Meanwhile, the ephemeral Ferlo River, 
which appears to have drained much of north central Senegal in the past as indicated by highly structured and stratified stream networks, joins the Senegal at the Lac de Guiers. The upper stretches of the Senegal River valley, beyond the confluence of the Senegal and Falémé, present three terraces, with the Falémé Stone Age sites (e.g. Sansandé) occurring within deposits of the lowermost terrace (Michel 1973; Chevrier et al., this volume).

Within the lower course of the Senegal River, the terrain is broadly divided between the Walo region, comprising the modern river course and its immediate flood plain, and the Ferlo region. The Ferlo comprises the gently sloped plains to the south of the river associated with the eponymous tributary, with limited presence of linear dune systems immediately south of the Senegal River, that are better established and more widespread on the north side. The Walo is formed of hydromorphic and vertic soils, representing Quaternary fluvial depositions which overlie Eocene sandstones. The Ferlo is formed of sandstone plateaus, dissected by valleys of an ancient drainage system and is covered in flat to gently rolling aeolian formations. A framework of Quaternary sedimentology in the lower Senegal Valley and its major tributaries proposed by previous researchers is presented in Table 1. However, the chronology presented in the table should be viewed with considerable caution given the lack of direct dates. Recent research is instead emphasising that deep and complex alluvial formations may have occurred more recently, in MIS 3, 2 and 1 (Chevrier et al., this volume).

Table 1 hereabouts

Figure 2 hereabouts

\subsection{Research History}

Detailed archaeological surveys in Senegal began in the second half of the $20^{\text {th }}$ century (e.g., Ravisé 1975, Camara, 2000; Diop 2000), reporting a very sparse and heterogeneous distribution of Stone Age artefacts (ESA, MSA and LSA), with the exception of the Dakar (the capital city) region and the Falémé River valley in the east of the country, which have since defined the current understanding on the Stone Age of Senegal (Table 2). The distribution of key previously identified sites is shown in Figure 2, and examples of MSA finds from Senegal are shown in Figure 3.

A number of caveats must be considered regarding these tentative sequences proposed for the Stone Age in Senegal. Firstly, the concentrations of Stone Age material in Dakar and the Falémé regions may be more apparent than real. In Dakar, major public works, such as the construction of buildings, roads and a sanitary canal, greatly facilitated the discovery of artefacts. In the eastern region, discovery 
was similarly aided by prospection for mineral deposits. Secondly, thanks to construction/prospection work and erosional processes, most Stone Age sites and find spots in both regions were found out of stratigraphic context (e.g. Laforgue 1925, Hubert 1922, Laforgue and Mauny, 1938, Corbeil et al.1948, Mauny 1949, 1950, Richard 1955, Dagan 1956, 1972, Hugot 1967, Descamps 1979, Diop 1976, 1980, 2000), limiting inference to broad typological considerations. While undoubtedly important, such typological considerations are also problematic because they have typically been implemented within methodological and interpretative frameworks developed for the Palaeolithic record of France without adjustment.

Table 2 hereabouts

Figure 3 hereabouts

Finally, there are no reliable chronometric age estimates for the proposed sequence and the phases and their subdivisions are problematic. For example, the very high typological diversity of the Tiemassassanian has led some researchers to consider this 'industry' to represent either a 'Middle' or an 'Upper Paleolithic' (Dagan, 1956, 1972; Descamps et Demoulin, 1969; Guillot and Descamps 1969; Descamps, 1979), while other have associated it with the Mesolithic (Davies, 1967) or Neolithic period (Hugot 1967, Dagan 1956, 1972). Notwithstanding these debates, reliable descriptions and analyses of both these apparent cultural facies (i.e., the Mousteroïd and the Tiemassassian) have not yet been conducted. However, a number of dates, broadly clustering around the Pleistocene/Holocene transition have recently become available for sites in the Falémé River Valley, which will aid in the reassessment of the existing schemes (see Chevrier et al., this volume).

\subsection{Lithic Technology}

The historic archaeological sites discovered in the Falémé River valley have generally been found in disturbed contexts (e.g., Karé, Saré, Oubol, Takoutala, Badoye) and are associated with an 'Acheulean' Early Stone Age (ESA) and a 'Middle' or recent Palaeolithic (MSA) (Camara and Duboscq 1983, 1984, 1987, 1990). The Stone Age sites of Sansandé ('Acheulean') and Djita ('final Acheulean') yielded ESA artefacts and Levallois technology in stratigraphic context. However, these early sites currently lack chronometric age estimates and the probable chrono-cultural attribution of these sites are problematic. For example, the "recent Palaeolithic" attribution is based solely on the presence of a few foliate points (Camara and Duboscq 1987). Geomorphological studies conducted in the Falémé, Gambia and Senegal valleys furthermore suggest that the formation of the different levels associated with Stone Age archaeology in the region occurred between 350 and $\sim 13.5 \mathrm{ka}$, a significant time range (Camara and Duboscq, 1987). This chronological framework is based on correlations between geomorphological observations and 
oceanic sediment cores along the Mauritanian littoral (Camara, 2000). Later stages, in particular the Pleistocene/Holocene transition and early Holocene period, are becoming more clearly understood (Chevrier et al., this issue).

Elsewhere in West Africa, chronometrically dated Stone Age sites are extremely rare. However, recently dated MSA sites suggest a timespan for this cultural phase of at least $\sim 150-12 \mathrm{ka}$, with population density apparently increasing towards the younger end of this range. At Ounjougou in southern Mali, dates for the MSA ranged from 150-30 ka for a series of occupations (Soriano et al., 2010). These assemblages consist of lithics produced on sandstone (sometimes trending into quartzite) and quartz. The diversity of MSA technology associated with the dated occurrences was interpreted by the excavators as evidence for several separate population incursions into the region (Robert et al., 2003; Soriano et al., 2010) (Fig. 4). A variety of reduction methods (e.g. Levallois, discoidal, anvil) occur through time, as do different forms of retouched tool (Soriano et al., 2010). The MSA at the site of Bilma (Niger) underlies a radiocarbon age estimate of $\sim 33 \mathrm{ka}$ and features Levallois reduction methods (Maley et al., 1971). At Birimi, in northern Ghana, an age estimate of sediments associated with MSA artefacts of 40 ka was obtained using OSL (Hawkins et al., 1996, Quickert et al., 2003) (Fig. 4). It should also be noted that even younger dates of $\sim 12 \mathrm{ka}$ have been reported for MSA material in south-eastern Senegal (Huysecom, 2013). Given these data, it is clear that the MSA extends from the Middle Pleistocene to the terminal Late Pleistocene.

Undated localities across West Africa are more numerous. However, piecing together the evidence together is compounded by the diversity of biogeographic zones in West Africa. In the Sahel, and more northerly latitudes of West Africa, the MSA appears to be often represented by industries with Levallois and/or discoidal reduction methods. Allsworth-Jones (1986) synthesised the results of numerous investigations in Nigeria and northern Cameroon, discovered primarily in alluvial deposits exposed by mining activities. In Nigeria, Nok and Zenabi were described as consisting of disc-cores and blades with prepared platforms (Fagg, 1956). Reconnaissance by Soper (1964) in northern Nigeria also led to the discovery of archaeological occurrences described as having a low 'heavy duty' tool component (according to the author, in contrast to the Sangoan industry) and the presence of disc and Levallois cores, flakes and blades with facetted platforms. Subsequent studies of Nok, Zenabi and assemblages from Pingell (Soper, 1964) respectively emphasised the importance of the Levallois technique and the possible presence of two facies for the MSA of Nigeria (Anozie, 1975; Allsworth-Jones, 1985). The 'Mai Lumba' facies appears to place a greater emphasis on the Levallois method compared to the 'Zenabi' facies (Allsworth-Jones, 1986) (Fig. 4). 
Figure 4 hereabouts

MSA technology appears to be similar in northern Cameroon. Mayo Louti (Marliac, 1973; Marliac and Gavaud, 1975) features a high number of Levallois cores and flakes. According to Allsworth-Jones (1986), who re-assessed the material, the Mayo Louti assemblages are very similar to the Mai Lumba assemblages. Although these assemblages are not directly dated, the archaeological level is situated within the Douroumian formation, which has sediments dated by radiocarbon to be between $\sim 35-25 \mathrm{ka}$ (Allsworth-Jones, 1986). Given advances in understanding of radiocarbon dating methods, the reliability of these estimates is currently unclear. Similar assemblages in northern Cameroun also include Sanguere (Fig. 4) (see Robert et al., 2003 for a brief synthesis). Some differences are apparent across the Sahelian and savannah regions of northern West Africa, however, and assemblages in Senegal, Guinea and Mali have been reported with varying emphases on either recurrent centripetal Levallois and unifacial discoidal methods and centripetal preferential Levallois methods (Fig. 3).

Assemblages from the southern regions of West Africa appear to have some distinct differences to those of the northern regions of West Africa described above. Southern Cameroon has only been investigated in detail by the Tokyo Metropolitan University Geographical Expedition to Cameroon, which identified numerous Stone Age sites described as Sangoan and Lupemban (see Allsworth Jones, 1986 for a synthesis), featuring large cutting and heavy-duty tools. Such sites have also been reported in Nigeria (Soper, 1956), the Ivory Coast (Chenorkian and Paradis, 1982) and Ghana (Nygaard and Talbot, 1976).

\section{Materials and Methods}

The SPP has conducted assessments of existing archaeological collections held at IFAN, Dakar, and commenced a new programme of field exploration to better understand the nature and context of Stone Age inhabitation of this key region. Initial prospection targeted the lower Senegal Valley, beginning shortly before the confluence of the Falémé and Senegal Rivers at Nayé and extending to Lac de Guier.

The field strategy was based on the investigation of ancient terraces, river cuts and relict channels and at hand-dug quarries along the interface of the Walo and Ferlo. These types of locations had already been identified as important for Stone Age finds and the interpretation of the Quaternary geomorphology of the Senegal River (Michel, 1973), as discussed above. Previously identified locations were reinvestigated and satellite data were used to identify new, potentially relevant locations for investigation. Targeted prospection was conducted at each location 
aiming to identify the presence of archaeological assemblages, their stratigraphic provenance and patterns of sedimentary diversity. Descriptions of sediment sequences are based upon field observations.

All artefacts from excavated contexts and from localised surface scatters were collected. At the large sites, representative collections were made, consisting of cores, core management flakes (e.g. platform management, core tablets, various débordant flakes, etc.), products and retouched pieces that could elaborate the reduction sequence as well as represent the range of retouched morphologies. Initial assessment and sorting of all collected artefacts was conducted in the field (i.e., number, artefact category, raw material). The collections were then representatively subsampled on the basis of these assessments (see Milne, 2009). The subsamples were then analysed in detail and basic typological classifications recorded alongside metric data (Table 3).

Table 3 hereabouts

\section{Results}

At the sites identified during our survey (Fig. 5), a common pattern of sediment formation was identified (Fig. 6), comprising an upper deposit of dune sands overlying a ferricrete weathering sequence, ranging from dismantled iron crust deposits to concretised sediment horizons. Some variation was observed in the presence of other stratigraphic units and how they fit within this common sequence. In total, Stone Age artefact collections were made at ten sites visited. Details of sediment sequences and the nature of Stone Age artefacts are presented for each site below. The details are summarised in Table 4 and Table 5 .

Figure 5 hereabouts

Figure 6 hereabouts

Table 4 hereabouts

\subsection{Nayé}

The village of Nayé is situated at N14 $24^{\prime} 12.3^{\prime \prime}, \mathrm{W} 12^{\circ} 12^{\prime} 14.9^{\prime \prime}$ on the banks of the Falémé River, shortly before its confluence with the Senegal. Ancient river terraces at Nayé consist of a thick sand cap overlying a thin layer of gravels. Artefacts were found on the surface of the sand. Multiple periods are represented, and artefacts include pottery. Stone tools probably largely represent the Holocene period and include artefacts made from chert, quartzite and quartz. Seven artefacts were 
collected eroding out of the gravels, in contrast to the other artefacts that were lying on the sand cap (Table 4, Table 5). That some of the finds are of MSA character (e.g. a Levallois core) may suggest the relatively close spatial and temporal articulation of LSA and late MSA industries here.

\subsection{Koungani}

A site located at N14 $50^{\prime} 09.0^{\prime \prime}, \mathrm{W} 12^{\circ} 26^{\prime} 03.4^{\prime \prime}$, close to the village of Koungani was identified. The site is located extremely close to the confluence of the Senegal and Falémé Rivers. The site consisted of a quartzite outcrop proximal to a relict river channel that may have been active during multiple periods of prehistory. Three artefacts were collected at Koungani, a quartzite discoidal core, a large quartzite recurrent Levallois core, and a likely Holocene aged chert blade core. The chert blade core was in extremely fresh condition and found in the bed of the river channel. The other cores were found at the foot of the raw material outcrop.

Table 5 hereabouts

\subsection{Dabià Quarry}

At Dabià (N15 54'24.6”, W1331'12.4'), dismantling iron crust deposits are widely exposed in the landscape, which are the focus of quarrying both here and the majority of other locations visited in our survey. In some exposures at Dabià, these ferruginous deposits include rare non-ferruginous clasts, typically quartzes or cherts, whereas elsewhere they are either absent or potentially obscured by cementation of the sediment matrix. Higher concentrations of non-ferruginous clasts are found in two deposits. The first comprises a mid-red sand matrix supported by moderately sorted round to sub angular clasts of chert, quartz and some ferruginous clasts, with lithic artefacts recovered from spoil heaps where this deposit has been quarried. This overlies a yellower sand matrix supporting sorted sub-round to subangular cherts and quartzes, but lacking any ferruginous component. A second exposure of this yellow non-ferruginous gravel is overlain by a pseudoconglomerate facies, with rare non-ferruginous grits. In some locations, pisolitic iron crust deposits clearly display gravel bed structures. In one exposure, pisolitic iron crust nodules were identified within a calcretised matrix.

At Dabià, 72 artefacts were collected and analysed, and of these 15 were transported for detailed analysis (Table 5). The quartzite raw material was of relatively low quality, with medium to large quartz inclusions. The source was not located. The three cores are all discoidal in character (Fig. 7). The flakes include two retouched artefacts (Fig. 7). Flakes tended to have highly variable platform angles $\left(\bar{x} 81.3^{\circ}, \sigma 20\right)$ which were either on the high (maximum, $106^{\circ}$ ) or the low side (minimum, $45^{\circ}$ ). The range of the angles, as well as the high and low values may reflect difficulty of 
flaking this raw material. The technological character of the flakes is consistent with discoidal reduction. This character is particularly evident on the core management flakes, one of which is the remnant of the entire surface of a discoidal core. Both the retouched flakes are denticulates, one on a débordant flake.

Figure 7 hereabouts

Two further sites were explored in this region, although neither resulted in the recovery of lithic artefacts. At Boki Saboudo (301-4)(N15²4'2.36"'; W13 26' $1.26^{\prime \prime}$ ) some variability in the colour of the iron crust deposits is evident, with more yellow and lighter red clasts comprising the upper, looser deposits, whereas more consolidated deposits preserving extensive bridging are a darker reddish brown colour, similar to deposits seen at Dabià.

At Tilagne Tokossel (N15 58'20.67"; W13³6'51.35'), the upper horizons of pseudoconglomerate depositscontain small to medium sized sub round to sub angular pebbles of chert and quartz. In some exposures a second horizon of pseudoconglomerates with non-ferruginous clasts is observed, containing small cobble sized tablets of black quartzite. This is separated from cemented, exclusively ferruginous deposits, with more plate-like than nodular form, by a thin horizon of sorted non-ferruginous grit and small to medium pebbles, comprising cherts and quartz.

\subsection{Djammal Quarry}

Djammal Quarry (N1630'27.2", W14 $27^{\circ}$ '57.4') presented the most varied upper dune sequence, with banded horizons varying between bright red, yellow and grey silty sands. The contact between this and the underlying unit is marked by the inclusion of fine grit inclusions in the upper deposit. A pedogenised horizon underlies the banded dune sands, grading from a greyish red to a reddish brown/brownish pink. Underneath this a non-ferruginised grit/small pebble horizon was observed, which is predominately yellow, but the basal $10 \mathrm{~cm}$ exhibits a redder colour. A sharp contact was observed with underlying iron crust deposits, which present concretions ranging in size from pebbles to small cobbles, varying in colour from red-brown to blue-black and exhibiting both rounded, nodular and angular forms. The basal unit observed in this sequence is a consolidated, sand-calcrete horizon. A single chert discoidal core was found on the surface of the iron crust deposits.

\subsection{Ndiayène Pendao}

The quarry at Ndayène Pendao (N16 $\left.29^{\prime} 03.6^{\prime \prime}, \mathrm{W}^{\circ} 05^{\circ} 54.4^{\prime \prime}\right)$ presented instances of ferricrete deposits appearing in the form of a mottled clay horizon (Nahon, 1986), 
with bleaching zones ranging in colour from yellows to purples. These occur in the lowest topographic settings that were examined at the site, and contrast with gritty, pseudo-conglomerate and pisolitic deposits observed in high positions in the landscape. Test excavations of the iron crust deposits identified a thin deposit of loose, fine and round pisolitic nodules underlying the dune sand cover that yielded lithic artefacts. This deposit is distinct from underlying pseudo-conglomerate deposits based upon the size of nodules, which change from $<5 \mathrm{~mm}$ to $>5 \mathrm{~mm}$ and frequently $>10 \mathrm{~mm}$, and the extent of fusing of the nodules, only evident in the lower deposits. The pseudo-conglomerate deposits were excavated to a depth of $\sim 20 \mathrm{~cm}$, including rare artefacts in the upper part of the deposit, before the extent of cementation prevented excavation with hand tools, corresponding to a similar horizon which has been quarried. A larger collection of artefacts was made from quarry spoil heaps that had targeted these two horizons. Elsewhere, ferruginous nodules have been identified both cemented within a calcrete horizon, and occurring as a consolidating deposit overlying pale yellow calcareous clays.

A scatter of surface artefacts was found in a very small and localised area of this large, hand-dug quarry, and quarry workers confirmed that no similar artefacts had been found elsewhere in the quarry. Test trenches at this site revealed stratified artefacts, including a finely made denticulated pointed Levallois flake. Preliminary analyses indicate that the technology is very similar to that found at Njideri and Madina Cheikh Omar, described below. The lithic artefacts from this important site include a probable core axe, basally thinned pieces, finely made points and denticulates, which are undergoing use-wear and residue analyses, and preferential and recurrent Levallois cores (Fig. 8). A programme of OSL dating at this site is also underway.

Figure 8 hereabouts

\subsection{Njideri}

Njideri (N16 $\left.26^{\prime} 49.4^{\prime \prime}, \mathrm{W} 15^{\circ} 38^{\prime} 27.04^{\prime \prime}\right)$ is one of the larger quarries that was inspected, first identified as a Stone Age site by Duboscq (1986). At this site there were numerous exposed sections presenting a thin dune sand cover over pseudopisolitic and pseudoconglomerate deposits. In one quarry pit, a different sequence was observed, in which pseudoconglomerate deposits grade into a mixed gravel deposit including chert and quartz clasts that supports a mid brown/grey yellow sand matrix. This mixed gravel horizon overlies a yellowish white calcareous clay horizon. A relatively large collection of lithic artefacts was recovered from quarry spoil (Fig. 9). 
The lithic material was technologically very similar to that from Ndiayène Pendao, and like the material from Bargny observed at IFAN (Figs. 3 and 8). A total of 441 artefacts were collected from surface and subsurface contexts at Njideri and subjected to initial analysis (Table 5). Of these, 119 were transported for detailed laboratory analyses, which are ongoing. In general, the state of preservation of the lithics was very good. The chert artefacts were all patinated in either a reddish brown patina or a white patina suggesting contact with water. However, edges and arises are not rounded or abraded and still sharp and relatively fresh. The quality of the chert varied considerably, as did that of the limestone and quartzite. The most abundantly used raw material was chert.

The eighteen cores transported for detailed analyses have a mean weight of $54.6 \mathrm{~g}(\sigma$ 46.9) and a mean maximum linear dimension of 53.5mm ( $\sigma$ 16.26). Prepared cores included Levallois and discoidal cores. Single and multiple platform cores were also present in the assemblage. The cores were typically of a small size, although a few larger cores were also evident. The Levallois cores were generally the smallest, with the exception of one large Levallois core $(186 \mathrm{~g})$, which had a preferential flake scar which plunged, taking a large section of the distal edge of the core with it. Of the eleven Levallois cores, two were recurrent centripetal cores and the remainder were centripetal preferential cores (Fig. 9). Two cores on flakes were of a similar, small size. One of the cores on flake exhibited a wide and well prepared faceted platform in contrast to the short length and thinness of the debitage surface. These characteristics indicate a previous, Levallois modality when the mass of the core had been greater. A further five multiplatform cores may also have been Levallois cores as traces of a hierarchy between surfaces can be observed. A number of flaking accidents, potentially relating to the small sizes of these multiplatform cores may have resulted in the abandonment of a Levallois modality in favour of opportunistic flaking.

The character of the Levallois cores themselves ranged from classic, finely made centripetal preferential and recurrent cores (Fig. 9), to cores that were conceptually Levallois, but whose preparation was rather steep and poorly constructed. Two discoidal cores were also present in the assemblage. These cores were flaked on both surfaces and had a classic biconical cross section.

Figure 9 hereabouts

No raw material locality has yet been found in the vicinity of Njideri and it is possible that the small size of the cores may relate to a scarcity of local, good quality raw material. The smallest cores from Njideri often exhibited extensive signs of crushing around the margins and in two instances the cores appear to be retouched on one lateral margin, which was used as a denticulated edge in both cases. One 
preferential Levallois core exhibited a double patina in which two flakes from the platform surface had been removed some time after the core had been abandoned. Although these features point to a scarcity of raw material, two cores bear traces of cortex, suggesting that the raw material package size may also have been small. It is therefore possible that the raw material may have been provenanced as rare, small to medium-sized river cobbles. The considerable variation in raw material quality and the presence of several, large core management flakes featuring a rounded, cortical morphology supports the view that the chert source was in the form of such cobbles.

Flakes include waste flakes and core management flakes (Table 5), indicate that some knapping took place on site. Core management flakes included small, thin platform management flakes, core tablets, débordant flakes and flakes which preserved both discoidal and recurrent Levallois surfaces that had become unmanageable due to the presence of central masses. On average, flake size (not including core management flakes) is small ( $\bar{x} 24.4 \mathrm{~g}, \sigma 21.6)$. The mean flaking length is $45.8 \mathrm{~mm}(\sigma 14)$, with a minimum of $26.1 \mathrm{~mm}$ and a maximum of $78.6 \mathrm{~mm}$. The mean width perpendicular to this length is $38.8 \mathrm{~mm}(\sigma 12.8)$, with a minimum of $16.1 \mathrm{~mm}$ and a maximum of $70 \mathrm{~mm}$. The mean thickness is $11.6 \mathrm{~mm}(\sigma 5.1)$, with a minimum of $4.3 \mathrm{~mm}$ and a maximum of $29 \mathrm{~mm}$. Platforms tended to be mostly plain (55\%), although dihedral and faceted platforms form $16 \%$ and $15 \%$ respectively. High flaking intensity is supported by the fact that centripetal flaking forms the largest category of dorsal scar patterns ( $29 \%$ ), followed by $18 \%$ perpendicular (i.e., two directions forming a right angle to each other).

The flakes were produced using a hard hammer, and some of the flakes were struck with such force that they exhibit a double bulb. This notwithstanding, there are many finely made flakes, including seven Levallois flakes, all made on chert (Fig. 9). No Levallois flakes made from limestone or quartzite were discovered, despite the presence of a limestone Levallois core.

Fourteen retouched flakes were found and collected from Njideri. A small number of flakes exhibit characteristics consistent with burning (e.g. surface gloss, crazing and tiny, macroscopically observable pitting). Of the retouched flakes, three appear to be tanged (Fig. 10), resembling equivalent pieces from the nearby site of Madina Cheikh Omar (Fig. 11). These tools are all unifacially worked to produce a tang or deep shoulder. Although the tang on Aterian tools from assemblages further north are usually modified on both faces, is not uncommon to find unifacially worked tangs (see e.g. Nami and Moser, 2010). In particular, such unifacially tanged pieces have been associated with unfinished pieces (Tixier, 1967), which in Senegal may account for their presence at a knapping site. 
These are the first tanged tools to be found in a clearly MSA context in West Africa.

Unfortunately, all three pieces are broken, missing the distal end of the tool. The tangs are in all cases produced on the proximal end of the flake and retouched on the dorsal surface. A further two pieces were basally thinned, and resembled those found at Ndiayène Pendao. One of these tools from Njideri is thinned bifacially, while the other is thinned only on the ventral side of the flake. Two foliates, one of which was extremely crude and possibly a preform, were also found (Fig. 10). Of the remainder of the tools, two are denticulated and the rest all exhibited semi-abrupt, regular retouch. Apart from the two bifacial foliates and one of the basally thinned pieces, the retouch is not invasive and limited to the margins of the flakes. The average length of retouch is $58.7 \mathrm{~mm}(\sigma 28.45)$.

Figure 10 hereabouts

\subsection{Djierigayé}

Djierigayé (N16 $\left.31^{\prime} 20.4^{\prime \prime}, \mathrm{W}^{\circ} 5^{\circ} 27^{\prime} 17.9^{\prime \prime}\right)$ presented a section with an upper horizon of red sands overlying a relatively thin, consolidated iron crust deposit varying with regards to the inclusion of quartz and chert clasts, that tapers away and is absent in some locations. The basal deposit observed is a pale, calcareous clay horizon. A biface/handaxe was found at this site, along with a number of other artefacts of a discoidal technological character. Local residents indicated that similar material could be recovered within the vicinity, although no further artefact find spots were located during our explorations. It is possible that this site represents a late Early Stone Age (ESA) or an early MSA assemblage.

\subsection{Madina Cheikh Omar}

Madina Cheikh Omar (N16 $\left.{ }^{\circ} 6^{\prime} 41.7^{\prime \prime}, \mathrm{W} 15^{\circ} 33^{\prime} 33.8^{\prime \prime}\right)$ preserved a suite of dune sands overlying pisolitic, pseudo-conglomerate and cemented ferricrete deposits. A total of 177 artefacts were collected from Madina Cheikh Omar, of which 39 were transported for analysis. The artefacts are technologically similar to those from Ndiayène Pendao and Njideri. The artefacts were mostly made from chert, with the occasional use of quartzite and limestone. The state of preservation was also similar to Ndiayène Pendao and Njideri in that artefacts were patinated but typically had sharp edges.

Figure 11 hereabouts

Of the eight cores transported for analysis, seven were Levallois cores and one was a single platform core constructed on a pebble with natural convexities. The Levallois 
cores consisted of four centripetal preferential cores (Fig. 11, c) and two recurrent centripetal cores. The final Levallois core consisted of a core fragment and it was therefore not possible to determine how the core had been exploited, although it had clearly been prepared in a centripetal fashion.

The cores were constructed with a varying level of skill. Both recurrent centripetal Levallois cores were abandoned due to the build of a central mass, which could not be removed. However, one core was abandoned at a much earlier stage of reduction (maximum linear dimension, $64.8 \mathrm{~mm}$ ) and another was abandoned almost at the exhaustion stage (maximum linear dimension, $31.2 \mathrm{~mm}$ ). The preferential Levallois cores are finely made and range in size from having a maximum linear dimension of $34 \mathrm{~mm}$ to $70 \mathrm{~mm}$.

The Levallois flakes were very finely made with chapeau de gendarme and finely faceted platforms with up to 11 facets (Fig. 11,a,d). Flakes were produced either through centripetal flaking or unidirectional convergent flaking, the latter of which was used to produce the two Levallois points found at the site. The Levallois flakes had a mean weight $19.7 \mathrm{~g}(\sigma 4.7)$, a mean number of scars of $5.8(\sigma 2.5)$ and a mean external platform angle $71^{\circ}(\sigma 7)$.

Non-Levallois flakes included core management elements, such as débordant flakes and core tablets and cortical flakes, indicating that some knapping took place on site. There was more variation amongst the flakes, reflecting their different functions and stages within the reduction continuum. The mean weight was $24.95 \mathrm{~g}(\sigma 26.9)$, the mean number of scars was $4.1(\sigma 2.7)$ and a mean external platform angle of $54.2^{\circ}(\sigma$ 7.1).

The seven retouched flakes included the proximal fragment of a tool that resembles a unifacially tanged or lozenge-shaped tool (Fig 11, b), one denticulate and a further five flakes featuring regular, semi-abrupt retouch. One of these is the distal fragment of a retouched point, and another is a retouched débordant blade.

\subsection{Ngnith}

Ngnith Quarry (N16 $\left.23^{\prime} 45.3^{\prime \prime}, \mathrm{W}^{\circ} 5^{\circ} 51^{\prime} 26.5^{\prime \prime}\right)$ also preserves a suite of dune sands overlying pisolitic, pseudo-conglomerate and cemented ferricrete deposits. The quarry is disused and features MSA type artefacts, including a distinct Levallois component. Flakes were made from diverse raw materials. 56 artefacts were collected (Table 5).

\subsection{Mbane}

Sediment exposures at Mbane (N16¹5' 5.569"; W1547' 23.91") occur on the opposite side of Lac de Guiers to Madina Cheikh Omar and Ngnith. The deposits present 
larger sizes of ferruginous nodules that preserve a greater degree of cementation than present at either of these other two, nearby sites, as well as including occasional non-ferruginous clasts. Here, these deposits overly a pale yellow, calcareous clay. Only twelve artefacts were found (Table 5), and the workers at the quarry reported that they had not seen any others.

\section{Discussion}

\subsection{Sediment Contexts}

The formations observed in our survey attest to both significant mobilisation and weathering of sediments at the margin of the Ferlo. Aeolian sediments, in the form of sand sheets and dunes, form a persistent cover to the underlying fluvial deposits, with better established, linear dune systems evident on the Mauritanian side of the Senegal River Valley. Aeolian inputs may have played a role in the depositional behaviour of the Senegal River within its lower course throughout the Quaternary period, although only the most recent phases of aeolian activity are clearly identifiable today.

The identification of iron crust deposits and calcareous clays offers some means to integrate our findings into earlier schemes of landscape evolution. Michel (1973) identified ferruginous duricrusts in the Senegal Valley as a Pliocene formation, with the possibility of later erosion and mobilisation of these deposits. The most cemented or least dismantled ferruginous deposits we have identified may correspond directly to Pliocene weathering and ferricrete formation. The diversity in the size, extent of fusing and stratification with other sediments suggests that many sites we have visited present a more complex picture of on-going dismantling of these duricrusts. The inclusion of iron crust nodules with other clastic material suggests fluvial dismantlement of ferricrete profiles and subsequent transport of nodular material at a number of locations in the upper course of the river valley that has been subject to survey. In contrast, in contexts further downstream, iron crust deposits do not appear mixed with fluvial materials, and are instead underlain by other facies of ferricrete development. In these instances, aeolian processes may also have played a role in dismantling the iron crust deposits.

\section{The presence of calcareous clays was noted at the base of numerous sediment} sequences, which attest to the presence of significant depths of standing water and are indicative of phases of heightened humidity. These horizons may correspond with the Middle Alluvial horizon identified by Camara and Dubosc (1987), and may be analogous to clay horizons at Sansandé. Other calcareous deposits, which include one instance of ferruginous nodules cemented by calcretes, indicate that alternative 
chemical weathering and precipitation processes to ferricretisation have been dominant in the recent geomorphological history of the Senegal Valley.

Synthesising our results within the framework devised by Camara and Duboscq (1987) is problematic until chronometric dating methods are employed both for the sites identified here, and to refine the relationships between sediment strata and associated Marine Isotope Stages presented in Table 1 for the wider Senegal River Valley. Similarly, as the majority of lithic artefacts recovered were from quarry spoil deposits, assessing the timing and sedimentary context of deposition cannot as yet be resolved. At Ndiayène Pendao, the excavation of artefacts from pisolitic and uppermost pseudo-conglomerate iron crust horizons offers some insight into their position within the stratigraphic sequence. The fresh appearance of buried lithic artefacts does not support significant mobility into the site, which may suggest that they became included within the stratigraphic profile through vertical deflation of the upper iron crust horizons. A similar scenario can be put forward at Njideri and Madina Cheikh Omar, yet recovery of artefacts in excavated contexts is required to test this. At Dabià, the lithic artefacts appear to derive from a fluvial gravel, and may therefore have been subject to some mobilisation and sorting prior to deposition. The context and nature of artefacts recovered at Djierigayé appears similar to those reported by Camara and Duboscq (1987) from the middle and lower Falémé valley. This may relate to an earlier phase of occupation of the Senegal Valley than the other sites reported, although constraining the artefact context further and assessing the potential for artefact transport is required.

\subsection{Lithic technology}

On the basis of previous research and the preliminary results presented, it is possible to make some initial observations about the MSA in Senegal. The sites discovered appear to range from indications of occasional knapping episodes to recurrent habitation sites at the edges an ancient Pleistocene course of the Senegal River. It is likely that this major source of fresh water repeatedly attracted hominins to the region, both as short and more long-term events. The size of the sites discovered in northern Senegal may indicate the latter in this area.

Sea level changes during the Pleistocene are likely to have had a significant impact upon the behaviour of the Senegal River, and the nature of Palaeolithic occupations nearby. Giresse and colleagues (2000) indicate that sea level rises are unlikely to have exceeded $4 \mathrm{~m}$ above current sea level, suggesting major inundations of the Walo are unlikely. Instead, sea level rises may have expanded the river delta and promoted low energy fluvial habitats further upstream. In contrast, lower sea levels will have promoted more energetic and incising fluvial regimes. As a result, evidence for MSA occupations around Richard Toll could indicate adaptations to a range of behaviours 
of the Senegal River. Refining the chronological contexts for both human and riverine behaviours are key to resolving the nature and variability of these relationships.

It is also possible that the sites discovered at least in part reflect the Senegal River's role in facilitating dispersals across West Africa, both into northern Africa and through the sub-Saharan area. Ndiayène Pendao, Njideri, Madina Cheikh Omar, Ngnith and Mbane are all technologically and typologically similar. The Levallois character of these assemblages also appears to be similar to others from the Fann region, such as Bargny as well as other possible MSA sites in the Falémé (Fig. 3). However, perhaps for chronological regions, there appears to be technological differences between the sites described in this paper and recently dated Late Pleistocene sites described elsewhere in the Falémé (see Chevrier et al., this volume). All the assemblages described in this paper also evidence similarities with other assemblages from across the northern regions of West Africa, discussed in section 2.3. It is likely that these similarities reflect both similar environments and common technological traditions. In addition to the Levallois component, Madina Cheikh Omar and Ndiayene Pendao have high numbers of multiplatform cores. Like Njideri, these appear to represent the final stages of core reduction on what were once Levallois cores. It is possible that higher numbers of multiplatform cores at these sites represent raw material clast size, economy and a need to obtain as many flakes as possible from the cores.

Besides indications of common technological features between the MSA sites discovered in the reconnaissance survey and others across West Africa, there are indications of similarities with other regions of Africa. The tanged tools found in the northern sites discovered and displayed in Figures 10 and 11 resemble tanged tools from North Africa (see Scerri, 2013). In particular, they resemble tanged tools in the process of manufacture, which is pertinent given their context at sites where flaking clearly took place. The Levallois components of the assemblage are also similar to Aterian assemblages to the north, including in nearby Mauritania (e.g., Pasty, 1999).

In contrast to the above, the bifacial foliates are of an oval form and quite unlike the foliates associated with Aterian assemblages in northwest Africa. These foliates instead resemble those from other regions of West Africa (e.g. at Birimi). On the other hand basally thinned pieces are found across Africa, including both in North Africa and West Africa. The assemblages also reflect a similar combination of Levallois methods to that of sites elsewhere in sub-Saharan Arica (e.g. Yellen et al., 2005; Shea, 2008). These technological characteristics may support the hypothesis that the Senegal River and its network of tributaries facilitated dispersal and population exchanges across a number of different biogeographic zones and regions 
of Africa. By identifying the first unequivocal evidence of tanged tools in a MSA context, we have illustrated the potential presence of technological continuity between North and West Africa.

The reconnaissance survey also identified assemblages that are distinctive. The assemblage from Dabià appears to be different, and based on discoidal, rather than Levallois technology. While a chronological element may be driving these differences, it is nevertheless interesting that a diversity of MSA technology may be evident in Senegal (see also Chevrier et al, this issue). Given the diversity through time at Ounjougou in neighbouring Mali this should not come as a surprise, although the assemblages discovered by the SPP evidence some differences to those from Ounjougou Unravelling the relative contributions of different sources of variability (spatial, temporal, functional, raw materials, etc.) remains a major research task, but which our initial research suggests will be facilitated by an abundant archaeological record.

Finally, although a dating programme at Ndiayene Pendao is underway, it is not yet possible to evaluate the chronology of the recent discoveries. It is therefore not yet possible to confidently develop the current sequence proposed for Senegal illustrated in Table 1. This notwithstanding, it is likely that the Senegal fluvial system repeatedly provided both conduits and refuges for populations throughout the Pleistocene. As a result we anticipate significant settlement complexity and a broad range of ages for MSA occupations.

\section{Conclusion}

Our preliminary results confirm the potential of Senegal and surrounding areas to contribute towards understanding Pleistocene hominin population dispersal and responses to environmental fluctuation. Together with previous discoveries from Ounjougou, Mali (Soriano et al., 2010) and elsewhere in Senegal (Chevrier et al., this volume), our findings contribute to a growing body of evidence demonstrating that the West African MSA is important for understanding Pleistocene demography and population diversity. Firstly, even the relatively limited knowledge so far available indicates a long timespan for the MSA of West Africa. A possible late persistence of the MSA in West Africa may reflect population isolation, persistence and resilience. Secondly, variability within the MSA of West Africa is increasingly evident, together with emergent indications that the region featured a complex demographic history. Core reduction strategies in the MSA assemblages of the Senegal River Valley are generally dominated by centripetal Levallois technology, with both recurrent and preferential methods employed. The discovery of tanged tools offers some 
suggestion of connections to the north, but remains to be evaluated in greater detail.

2 Other technological features have demonstrated the enchainment of the Senegalese

3

4

5 assemblages within the wider MSA, particularly of the surrounding, semi-arid regions along the same latitude.

While it is premature to discuss detailed demographic hypotheses, it seems evident that the wider context of the MSA assemblages described represents the interface between sub-Saharan (tropical) Africa and the arid Saharo-Arabian belt. For these reasons, the MSA of Senegal offers important information for understanding Pleistocene demography and intra-African dispersals, which involved the subsequent adaptation to different environments. The region may yet prove important for understanding hominin admixture and late population persistence. The refinement of our understanding of Pleistocene Senegal and wider West Africa hangs on the development of a robust chronological framework and the comparison of lithic assemblages from sites with good stratigraphic integrity. Such developments may well demonstrate that West Africa has as much to offer to our understanding of human prehistory as the more intensively researched areas of the continent.

\section{Acknowledgments}

We thank the Lorne Thyssen Research Fund for Ancient World Topics and the Gerald Averay Wainwright Fund for supporting this research. We are also grateful to the University of Cheikh Anta Diop and the Instut Fondamental Afrique Noir for permission to conduct research in Senegal. We also thank Alicia Hawkins and an anonymous reviewer for their extremely helpful and constructive comments on our manuscript.

\section{References}

Allsworth-Jones P. 1985. The Middle Stone Age north of the Jos Plateau: a preliminary report. West African Journal of Archaeology 11, 1-24.

Allsworth-Jones P. 1986. Middle Stone Age and Middle Palaeolithic: the evidence from Nigeria and Cameroun. In G.N. Bailey and P. Callow (eds.), Stone Age Prehistory, 153-68. Cambridge University Press: Cambridge. 
1 Allsworth-Jones P, Harvati K, Stringer C. 2010. The archaeological context of the Iwo

2 Eleru cranium from Nigeria and preliminary results of new morphometric studies.

3 In P. Allsworth-Jones (ed.), West African archaeology: new developments, new

4 perspectives, 29-42. BAR International Series 2164.

5

6 Alves, I., Sramkova Hanulova, A., Foll, M., Excoffier, L. 2012. Genomic data reveal a 7 complex making of humans. PLoS Genetics 8, e1002837 (2012).

8

9

Anozie, F. 1975. Contribution à l'étude de la préhistoire de l'Afrique occidentale.

Unpublished PhD thesis, University of Bordeaux 1.

Barham, L. and Mitchell, P. 2009. The First Africans: African archaeology from the earliest toolmakers to most recent foragers. Cambridge World Archaeology, Cambridge University Press: Cambridge.

Braconnot, P., Otto-Bliesner, B., Harrison, S., Joussaume, S., Peterchmitt, J.-Y., AbeOuchi, et al. 2003. Results of PMIP2 coupled simulations of the Mid-Holocene and Last Glacial Maximum - part1: experiments and large-scale features. Climate Past 3, 261-277.

Brothwell D, Shaw T. 1971. A Late Upper Pleistocene Proto-West African Negro from Nigeria. 6.(2): Man (new series), 221-227.

Camara, A. 2000 Le Paléolithique ancien. In R. Vernet (ed.), L'Archéologie en Afrique de l'Ouest Sahara et Sahel, 239-256. Editions Sépia.

Camara, A. Duboscq B. 1983. Découverte et fouille d'un site acheuléen en stratigraphie à Sansandé (région de Tambacounda, Sénégal). Notes africaines 180, 6171.

Camara, A., and Duboscq, B. 1984. Le gisement préhistorique de Sansandé, Basse Vallee de la Falémé, Sénégal: approche typologique et stratigraphique.

L'Anthropologie 88, 377-402. 
1 Camara, A., and B. Duboscq. 1987. Contexte chronostratigraphique des outillages du

2 paléolithique evolué dans l'est du Sénégal. L'Anthropologie 91, 511-519.

3

4 Camara, A., and Duboscq, B. 1990. La fouille d'un site Acheuléen a Djita (Basse

5 Vallee de la Falémé, Sénégal. L'Anthropologie 94, 293-304.

6

7 Chenorkian, R. and Paradis, G. 1982. Une industrie Paléolithique découverte dans la

8 «Terre de Barre » d'une terrasse proche d'Anyama (region d'Abidjan). Nyame Akuma $9 \quad 21,18-27$.

10

Chevrier, B., Rasse, M., Lespez, L., Tribolo, C., Hajdas, I., Guardiola, M., Lebrun, B., Leplongeon, A., Camara, A., Huysecom, E. In Press. West African Palaeolithic history: New archaeological and chronostratigraphic data from the Falémé valley, eastern Senegal. Quaternary International.

Corbeil R., Mauny R., Charbonnier J. 1948. Préhistoire et protohistoire de la presqu'île de Cap-vert. Bulletin de l'IFAN, série B, tome X, 378-460.

Crevecoeur, I., Semal, P., Cornelissen, E., Brooks, A.S. 2010. The Late Stone Age human remains from Ishango (Democratic Republic of Congo): contribution to the study of the African Late Pleistocene modern human diversity. American Journal of Physical Anthropology S50: 87.

Dagan, Th. 1956. Le site préhistorique de Tiemassas (Sénégal). Bullettin de l'IFAN 18 B, (3-4), 432-461.

Dagan, Th. 1972. Les gisements préhistoriques de Tiémassas et de Pointe Sarène. Actes du Vlème Cong. Panaf. Préhist Chambery, 92-94.

Davies O. 1967. West Africa before the Europeans: archaeology and prehistory. London: Metheun. 
Descamps, C. 1979. Contribution à la préhistoire de I'Ouest sénégalais. Travaux et Documents, volume II, Université de Dakar, Faculté des Lettres et Sciences Humaines, Département d'Histoire.

Descamps, C. and Démoulin, D. 1969. Stratigraphie du gisement préhistorique du Cap Manuel (Dakar). B.11F.A.N. (Séries A) 31, 739-51.

Diop, A. 1976. Contribution la connaissance du Paléolithique post-acheuléen dans la presqu'île du Cap-Vert. Mémoire de maîtrise Université Cheikh Anta Diop de Dakar (unpublished).

Diop A. 1980. Découverte d'un biface à Biseau terminal à Djita (Sénégal Oriental). Notes Africaines, n¹67.

Diop, A. 2000. Les industries du Paléolithique post-acheuléen au Sénégal. In R. Vernet (ed.), L'Archéologie en Afrique de l'Ouest. Sahara et Sahel, 257-268. Editions Sépia.

Duboscq B. 1986. Le moyen niveau alluvial et les sites moustéroïdes de la vallée du Sénégal. In livret-guide excursion $n^{\circ} 1$ : Nord Sénégal, Symposium International ASEQUA/INQUA, Dakar, April 1986, pp. 67-67.

Fagg, B. 1956. An outline of the Stone Age of the plateau Minesfield. Proceedings of the $3^{\text {rd }}$ International West African Conference, Ibadan, 1949, 203-222.

Garrigan, D., Mobasher, Z., Kingan, S.B., Wilder, J.A., Hammer, M.F. 2005. Deep haplotype divergence and long-range linkage disequilibrium at Xp21. 1 provide evidence that humans descend from a structured ancestral population. Genetic Society of America 170 (4), 1849-1856.

Giresse, Barusseau, J.-P., Causse, C., Diouf, B. 2000. Successions of sea-level changes during the Pleistocene in Mauritania and Senegal distinguished by sedimentary 
facies study and U-Th dating. International Journal of Marine Geology, Geochemistry and Geophysics 170, 123-139.

Guillot R. and Descamps, C. 1969. Nouvelles découvertes préhistoriques à Tiémassas (Sénégal). B.I.F.A.N. B 31, 602-37.

Gunz, P, Bookstein, F. L, Mitteroecker, P, Stadlmayr, A, Seidler, H, and Weber, G. W. 2009. Early modern human diversity suggests subdivided population structure and a complex out-of-Africa scenario. PNAS 106, 6094-6098.

Hammer, M.F., Woerner, A.E., Mendez, F.L., Watkins, J.C., Wall, J.D. 2011. Genetic evidence for archaic admixture in Africa. PNAS 108, 15123-15128.

Harvati K, Stringer C, Grün R, Aubert M, Allsworth-Jones P, et al. 2011. The Later Stone Age Calvaria from Iwo Eleru, Nigeria: Morphology and Chronology. PLoS ONE 6(9): e24024. doi: 10.1371/journal.pone.0024024

Hawkins, A., Casey, J., Godfrey-Smith, D., D’ Andrea, A.C. 1996. A Middle Stone Age component at the Birimi site, Northern Region, Ghana. Nyame Akuma 46, 34-36.

Hijmans, R.J., S.E. Cameron, J.L. Parra, P.G. Jones and A. Jarvis, 2005. Very high resolution interpolated climate surfaces for global land areas. International Journal of Climatology 25: 1965-1978.

Hubert, H. 1922. Objets anciens de l'Afrique Occidentale B. BCEHS, 5, 382-399.

Hugot, J.H. 1967. Le Paléolithique terminal dans l'afrique de l'ouest. In W.W. Bishop and J.D. Clark (eds.), Background to Evolution in Africa, 529-555. London and Chicago: University of Chicago Press. 
1 Huysecom, E. 2013. From Mali to Senegal: the research of the "Ounjougou Team". Paper

2 presented at African Archaeology Research Day 2013 at the Sainsbury institute of

3 Art, University of East Anglia, Friday $1^{\text {st }}$ November 2013.

4

5 Huysecom, F., Loukou, S., Mayor, A, Jeanbourquin, C, Chaix, L, Chevrier, B., et al.

6 2014. Vallée de la Falémé (Sénégal oriental) et Parc national des îles Eotilé (Côte

7 d'Ivoire): la 16ème année de recherche du programme «Peuplement humain et

8 paléoenvironnement en Afrique ». SLSA Rapport annuel, 2013, 113-176.

9

10

Jennings, R.P., Singarayer, J., Stone, E.J., Krebs-Kanzow, U., Khon, V., Nisancioglu, K.H., et al. In Press. The greening of Arabia: Multiple opportunities for human occupation of the Arabian Peninsula during the Late Pleistocene inferred from an ensemble of climate model simulations. Quaternary International.

Laforgue, P. 1925. Etat actuel de nos connaissances sur la préhistoire en Afrique Occidentale Française. Bulletin du Comité d'Etudes Historiques et Scientifiques de l'Afrique Occidentale Française 8 (1), 105-171.

Laforgue, P. and Mauny, R. 1938. Contribution à la préhistoire du cap-vert. Bulletin du Comité d'Etudes Historiques et Scientifiques de l'Afrique Occidentale Française 21 (2), 325-343.

Maley, J., Roset, J.-P., Servant, M. 1971. Nouveaux gisements préhistoriques au Niger oriental, localisation stratigraphique. Bulletin de liaison de l'A.Se.Qua. 31, 9-18.

Marliac, A. 1973. L'état des connaissances sur le paléolithique et le néolithique d Cameroun. Colloque International du CNRS, Contribution à la Recherche Ethnologique a l'Histoire des Civilisations du Cameroun, 1-45. Paris.

Marliac, A. and Gavaud, M. 1975. Premiers éléments d'une séquence paléolithique au Cameroun septentrional. Bulletin de l'ASEQUA 46, 53-66. 
1 Mauny, R. 1949. Sur la préhistoire de la presqu'île du Cap Vert. Etudes Sénégalaises 1,

2 I.F.A.N., 239-251.

3

4

5

6

7

8

9

10

11

12

13

Mauny, R. 1950. Découverte d'un biface Acheuléen à Dakar. Notes Africaines 45, 3-4.

Mendez, F.L., Krahn, T., Schrack, B., Krahn, A.-M., Veeramah, K.R., Woerner, A.E., Fomine, F.L.M., Bradman, N., Thomas, M.G., Karafet, T.M., Hammer, M.F. 2013. An African American Paternal Lineage Adds an Extremely Ancient Root to the Human Y Chromosome Phylogenetic Tree. American Journal of Human Genetics 92 (3), 454459 .

Michel, P. 1973. Les bassins des fleuves Sénégal et Gambie: étude géomorphologique. Mémoires ORSTOM, no. 63, Editions de l'Office de la Recherche Scientifique et Technique Outre-mer.

Milne, S.B. 2009. Debitage sample size and its implications for understanding lithic assemblage variability. Canadian Journal of Archaeology 33, 40-64.

Nahon, N.B. 1986. Evolution of Iron Crusts in Tropical Landscapes. In, S.M. Colman, D.P. Dethier (Eds.), Rates of Chemical Weathering of Rocks and Minerals. Academic Press, Orlando, pp. 169-191

Nami, M. and Moser, J. 2010. La Grotte d'Ifri n'Ammar Tome 2, Le Paleolithique Moyen. Forschungen Zur Archaologie Aussereuropaischer Kulturen.

Nygaard, S.E. and Talbot, M. R. 1976. Interim report on the excavations at Asokrochona, Ghana. West African Journal of Archaeology 6, 13-19.

Otto-Bliesner, B. L., Marshall, S. J., Overpeck, J. T., Miller, G. H., \& Hu, A. 2006. Simulating Arctic climate warmth and icefield retreat in the last interglaciation. Science 311(5768), 1751-1753. 
1 Pasty, J-F. 1999. Contribution à l'étude de l'Atérien du nord mauritanien. BAR

2 International Series 758.

3

4 Quickert, N.A., Godfrey-Smith, D.I., Casey, J.L. 2003. Optical and

5 thermoluminescence dating of Middle Stone Age and Kintampo bearing sedmients

6 at Birimi, a multi-component archaeological site in Ghana. Quaternary Science Reviews

$7 \quad 22,1291-1297$.

8

9 Rasse, M., Soriano, S., Tribolo, C., Stokes S. and Huysecom, E. 2004. La séquence pléistocène supérieur d'Ounjougou (Pays dogon, Afrique de l'Ouest): évolution géomorphologique, enregistrements sédimentaires et changements culturels. Quaternaire 15(4): 329-41.

Ravisé, A. 1975. Recensement des sites paléolithiques et néolithiques du Sénégal. Bulletin de l'I.F.A.N 37 (1), 234-245.

Richard, F. 1955. Contribution à l'étude de la stratigraphie du quaternaire de la Presqu'île du Cap-Vert (Sénégal). Bulletin de la Société préhistorique de France 52 (1-2), 80-88.

Rightmire, G. P. 2009. Out of Africa: modern human origins special feature: middle and later Pleistocene hominins in Africa and Southwest Asia. PNAS USA 106, 1604616050.

Robert, A., Soriano, S., Rasse, M., Stokes, S. And Huysecom, E. 2003. First chronocultural reference framework for the West African Paleolithic: New data from Ounjougou, Dogon Country, Mali. Journal of African Archaeology 1, 151-169.

Scally, A. and Durbin, R. 2012. Revising the human mutation rate: implications for understanding human evolution. Nature Reviews Genetics 13, 745-753. 
1 Scerri, E. M. L. 2013. The Aterian and its place in the North African Middle Stone

2 Age. Quaternary International 300, 111-130.

3

4 Scerri, E. M. L., Drake, N., Jennings, R., Groucutt, H. S. 2014. Earliest Evidence for 5 the Structure of Homo sapiens Populations in Africa. Quaternary Science Reviews 101, $6 \quad 207-216$

7

8

9

Shea, J.J., 2008. The Middle Stone Age archaeology of the Lower Omo Valley Kibish Formation: Excavations, lithic assemblages, and inferred patterns of early Homo sapiens behavior. Journal of Human Evolution 55, 448-485

Soper, R.C. 1956. The Stone Age in Northern Nigeria. Journal of the Historical Society of Nigeria 3, 175-194.

Soriano, S., Rasse, M., Tribolo, C. and Huysecom, E. 2010. Ounjougou: a long Middle Stone Age sequence in the Dogon country (Mali), in: P. Allsworth-Jones (ed.) West African archaeology. New developments, new perspectives (BAR International series 2164): 1-14. Oxford: Archaeopress.

Stringer, CB. 1974. Population relationships of later Pleistocene hominids: a multivariate study of available crania. Journal of Archaeological Science 1, 317-342.

Tixier, J. 1967. Pièces pédonculées atérienne du Maghreb et du Sahara. Fiches Typologique Africaines 3, Musée National d'Histoire, Paris.

Veeramah, K.R., Hammer, M.F. 2014. The impact of whole-genome sequencing on the reconstruction of human population history. Nature Reviews Genetics 15, 149-162.

Willoughby, P. 2007. The Evolution of Modern Humans in Africa. AltaMira Press. 
1 Yellen, J., Brooks, A., Helgren, D., Tappen, M., Ambrose, S., et al. 2005. The

2 Archaeology of the Aduma Middle Stone Age sites in the Awash Valley, Ethiopia.

3 PaleoAnthropology 2005, 25-100. 